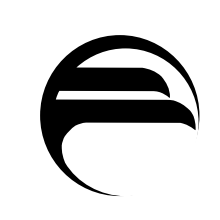

Federal Reserve BANK of Philadelphia

Ten Independence Mall

Philadelphia, Pennsylvania 19106-1574

(215) 574-6428, www.phil.frb.org

\title{
Research Department
}

\section{WORKING PAPER NO. 96-1}

\section{BANK EQUITY STAKES IN BORROWING FIRMS}

AND FINANCIAL DISTRESS

Mitchell Berlin

Federal Reserve Bank of Philadelphia

Kose John

Anthony Saunders

Stern School of Business, New York Uiversity

December 1995 
WORKING PAPER NO. 96-1

\title{
BANK EQUITY STAKES IN BORROWING FIRMS AND FINANCIAL DISTRESS
}

\author{
Mitchell Berlin \\ Federal Reserve Bank of Philadelphia
}

\author{
Kose John \\ Anthony Saunders \\ Stern School of Business, New York University
}

December 1995

Acknowledgments: We are grateful to Franklin Allen, Craig Holden, Loretta Mester, Manju Puri, Raghuram Rajan, Sherrill Shaffer, Anjan Thakor, Patricia Wilson, an anonymous referee, seminar participants at the Board of Governors, the 1993 BRC/JFI Symposium on Financial Institutions, and the 1993 Western Finance Association meetings for helpful comments and discussions. They are not responsible for any remaining errors. Berlin thanks the Leonard N. Stern School of Business and the Indiana University School of Business for financial support. John thanks the Charles William Gerstenberg Chair and the Bank and Financial Analysts Association Faculty Fellowship for financial support. Saunders thanks the John M. Schiff Chair for financial support. The views expressed here are ours and do not necessarily represent the views of the Federal Reserve Bank of Philadelphia or the Federal Reserve System. 


\title{
Bank Equity Stakes in Borrowing Firms and Financial Distress
}

\begin{abstract}
We derive the optimal financial claim for a bank when the borrowing firm's uninformed stakeholders depend on the bank to establish whether the firm is distressed and whether concessions by stakeholders are necessary. The bank's financial claim is designed to ensure that it cannot collude with a healthy firm's owners to seek unnecessary concessions or to collude with a distressed firm's owners to claim that the firm is healthy. To prove that a request for concessions has not come from a healthy firm/bank coalition, the bank must hold either a very small or a very large equity stake when the firm enters distress. To prove that a distressed firm and the bank have not colluded to claim that the firm is healthy, the bank may need to hold equity under routine financial conditions.
\end{abstract}




\section{Bank Equity Stakes in Borrowing Firms and Financial Distress}

\section{Introduction}

Recent years have witnessed an increasing interest in the behavior of large investors and their influence on firm behavior. This interest has been stimulated by the growing size and influence of institutional investors in the U.S. economy and also by the perception that banks in Germany and Japan-so called "bank-centered" economies--have played an especially productive role in the successes of their respective economies. Thus, we now have a number of empirical studies seeking evidence for distinctive channels through which close bank ties might influence firm performance. Notably, researchers have found evidence that close ties between Japanese banks and firms may reduce the costs of financial distress

for borrowing firms. ${ }^{1}$ The evidence for Germany is more mixed. ${ }^{2}$ Even granting the unsettled state of our empirical knowledge, it is natural to ask which aspects of firm-bank relationships may be important in improving firm performance.

It has often been suggested that bank equity holdings in the firms to which they lend-symptomatic of firm-bank relationships in Japan and Germany--may facilitate more effective bank interventions when firms are distressed. For example, a bank's ability to take an equity position in a distressed firm might reduce agency conflicts between the bank and the firm's shareholders that would lead to excessive liquidation or myopic investment decisions. ${ }^{3}$ However, the empirical evidence for this view is mixed. For Germany, Edwards and Fischer (ch. 7, 1994) report that bankers seldom take equity stakes when firms enter financial distress. For the United States, James (1993) dispels the common belief that regulatory restrictions prevent banks from taking equity positions in financially distressed firms, yet finds evidence that conflicts among fixed claimants restrict bank equity positions in distressed restructurings. ${ }^{4} \quad$ Nonetheless, recent studies suggest that banks in the U.S.--like banks in Japan--do play an important role in facilitating restructurings in the U.S. (For the U.S., see Gilson, John, and Lang 
(1990) and James $(1993,1994))$.

Of course, taking larger equity stakes in financially distressed firms is not the only conceivable channel through which banks' equity powers might affect the costs of financial distress for borrowing firms. There is some evidence from Japan and Germany that bank equity stakes in healthy firms are associated with reduced agency costs and, perhaps, reduced costs of financial distress. ${ }^{5}$ Although banks in the U.S. have broad rights to take equity stakes when their debt claims are impaired, they cannot hold equity on a routine basis. ${ }^{6}$

Against the steady accumulation of empirical work, there has been relatively little theoretical work that would shed any light on the potential efficiencies--or costs--of expanded equity powers for banks, or, for that matter, the optimal structure of the financial claim for any large institutional investor. Our paper examines theoretically the effect of the structure of an informed lender's financial claim on its own behavior when a borrowing firm enters financial distress. In particular, we examine how the structure of an informed lender's financial claim affects its ability to resolve conflicts between a potentially distressed firm and the firm's non-equity stakeholders, such as suppliers and customers who have a direct interest in the firm's continuing viability and whose business is essential to the firm's existence. ${ }^{7}$ Assuming no a priori regulatory restrictions on the bank's equity powers, we show how the debt-equity structure of the bank's claim affects its ability to play a constructive role in mitigating conflicts both between the firm's owners and its fixed claimants and also among the claimants themselves. ${ }^{8}$

Specifically, a firm in financial distress may be unable to continue production profitably without concessions by its long-time suppliers and customers. At the same time, these stakeholders--who may face substantial costs of switching their business to other firms--will be suspicious of any plea by the firm for financial concessions, viewing it as an attempt by a healthy firm to renege on past contractual 
agreements and to capture rents at the stakeholders' expense. Of course, stakeholders might undertake the costs of monitoring the firm's true financial condition themselves. But as Fama (1990) and others have argued, bankers evaluate borrowers' financial health routinely in their capacity as lenders, so nonequity stakeholders need not duplicate the bank's efforts as long as the bank can be relied on to tell the truth about the firm's financial condition. Whether stakeholders can, in fact, rely upon the bank to tell the truth crucially depends on the structure of the bank's financial claim on the firm. An equity stake in the firm--which gives the bank a residual claim on the firm's profits--tends to align the bank's interests with the firm's owners against the firm's non-equity stakeholders. This can create suspicions in stakeholders' minds that the bank and firm will collude to extract rents by seeking unwarranted reductions in the stakeholders' contractual claims.

On the other hand, non-equity stakeholders with fixed claims may also be suspicious of statements made by a bank holding a pure debt claim on the firm--if this debt claim has greater priority than their own. Specifically, a bank with a pure debt claim and a financially distressed firm may collude to convince non-equity stakeholders that the firm's prospects are healthy and that no concessions are necessary. This can occur when the distressed firm's owners have relatively weak bargaining power vis a vis the bank in contract negotiations and when deadweight bankruptcy costs are low. Then, given the high likelihood of bankruptcy if stakeholders do not scale down their claims, the bank's higher priority allows it to capture nearly all of the firm's revenues (net of the deadweight bankruptcy costs) and the stakeholders are effectively expropriated.

Although a subordinated debt claim would allay stakeholders' suspicions, it may be difficult for the banker to credibly subordinate its own debt claim to those of the firm's input suppliers and long-term customers for two reasons. ${ }^{9}$ First, its superior information may permit the bank to take collateral when the firm's condition worsens (but before the deterioration becomes public information). Second, many 
of these stakeholders have only implicit contracts with the firm. Hence, a bank equity claim on the firm may be the only means for the bank to credibly subordinate a sufficient fraction of its claim to uninformed stakeholders.

In this paper, we show that the optimal dynamic financial claim for an informed bank lender has the following characteristics: (i) Should a firm enter financial distress--where both the bank and the firm's stakeholders must make concessions for the firm to continue efficiently--there are strict limits on the bank's feasible equity stake. Specifically, the bank's equity share in the distressed firm must be either near zero or near one, but it cannot lie within some intermediate range. By not holding an equity share within some intermediate range, the bank assures stakeholders that it has not formed a coalition with a healthy firm to extract rents through unnecessary contractual concessions. (ii) The bank's initial claim (its claim on the healthy firm) may require a minimum equity component to assure stakeholders that the bank and the firm will not collude to portray the firm as healthy even when it has entered distress. In our model, this type of collusion is possible if firm insiders' bargaining power in financial distress is weak and if deadweight bankruptcy costs are sufficiently small. If these conditions hold, and if the bank is unable to credibly subordinate its own debt claim to stakeholder claims, then the bank optimally holds an initial equity share and retains this equity share as long as the firm remains healthy. ${ }^{10}$

Beyond the particular banking setting we have chosen, our model of contract renegotiations is a particular example of a signaling model that, to our knowledge, has not been examined before. In this signaling model: (i) two informed agents produce a signal about the state of the world to an uninformed third agent, and (ii) the signal arises as the result of bargaining between the informed agents. The main insight of the model is that contracts can be designed to create conflicts of interest between informed agents, which generate a particular structure for the bargaining game and create signaling possibilities that would not otherwise arise. In turn, the contractually created conflicts of interest can be used to 
mitigate the informed agents' joint incentives to exploit the uninformed agents. In our setting, contracts are designed to create conflicts between the firm and the bank over the division of rents that might be expropriated from stakeholders, thereby overcoming the firm's and bank's joint interest in colluding to capture those rents. We believe that variations of this signaling model might usefully be applied to settings other than our particular application.

Our paper has a number of connections with various strands of the extant literature. The main connections are discussed in Section 2. In Section 2.2. we elaborate on the relationship between our paper and others that examine firms' incentives to seek unnecessary concessions from uninformed creditors (Brown, James, and Mooradian (1993) and Heinkel and Zechner (1993)) and in which informed investors' contracts are designed to prevent the exploitation of uninformed outsider investors (Admati and Pfleiderer (1994). In Section 2.5 we discuss the relationship between our paper and others that make predictions about the optimal priority for the claims of an informed lender (Berlin and Mester (1992), Brown, James and Mooradian (1993), Diamond (1993), Fama (1990), Gorton and Kahn (1993), and Rajan (1992)). ${ }^{11}$

Our paper proceeds as follows. We describe the model in the first section. In Section 2 we derive the structure of the bank's optimal financial claim. The final section summarizes and concludes.

\section{The Model}

\subsection{Agents}

There are three risk-neutral agents: the firm's owners (the firm), the firm's banker (the bank), and the firm's non-equity stakeholders, whom we model as a single input supplier (the supplier). Throughout, we distinguish between the firm's owners and the bank, even though the bank may hold equity in the firm. Without loss of generality, we assume a zero risk-free interest rate. Both the loan market and the input 
market are competitive when the firm signs initial contracts with the bank and the supplier.

\subsection{Production}

The model has three dates: Initial investments are made on date 0 , the continuation/liquidation decision is made on date 1 , and revenues are produced on date 2 . See Figure 1 for a time line representation of the model.

\section{The firm}

At date 0 , the firm invests $X_{o}$ dollars; for simplicity we assume that all of the funds for the initial investment come from the bank. ${ }^{12}$ This initial investment allows the firm to learn more about the distribution of returns on a risky project at date 1 . At this date, continued production requires $\mathrm{X}$ additional dollars from the firm's bank--which is assumed to be the sole source of such funds. ${ }^{13}$ Projects do not produce any revenues until date 2 .

Date 2 project revenues may take one of two values $R_{g}$ or $R_{b}$, with $R_{g}>R_{b}$. Uncertainty about ultimate project revenues is resolved sequentially (see Figure 1). Specifically, at time 0 the firm has a prior probability $\theta$ of being a healthy type $\left(t=t_{h}\right)$ at date 1 and a $(1-\theta)$ probability of being a distressed type $\left(t=t_{d}\right)$ at date 1 . Letting the subscript $j$ index the firm's type, a type $t_{j}$ firm has date 2 revenues $R_{g}$ with probability $p_{j}$ and $R_{b}$ with probability $\left(1-p_{j}\right)$, where $p_{h}>p_{d}>0$. Thus, at date 1 there remains some residual uncertainty about the firm's ultimate revenues. If a firm with revenues $R_{k}, k=g, b$, defaults on its contractual obligations at date 2, deadweight bankruptcy costs B are borne and date 2 revenues are $R_{k}$ B. ${ }^{14}$

In addition to extra funds $(\mathrm{X})$ at date 1 , continued production requires the purchase of an essential input from the supplier at date 1 . If sufficient funds cannot be secured, or if the supplier does not provide the input, the firm's assets must be liquidated at date 1 and production by the firm is discontinued. Since we are concerned about states where liquidation is inefficient, we assume for simplicity that the 
liquidation value of the firm at date 1 is zero. If the firm is liquidated early, the firm's owners have an outside employment opportunity between dates 1 and 2 that yields net income $\mathrm{w}$ at date 2 . If managerial control rents are important, we might have $\mathrm{w}<0$.

\section{The supplier (stakeholders)}

At date 0 , the supplier decides whether or not it wishes to set up a supply relationship with the firm. A supply relationship requires dedicated assets; that is, the supplier's assets are oriented toward producing inputs for the firm rather than for other potential purchasers. If a relationship is established, the supplier can (but may not) choose to produce the input for the firm at cost $\mathrm{c}$ at date 1 . If the supplier and firm have entered into a supply relationship, but the supplier chooses not to sell to the firm, the input can be sold elsewhere, but only for a net profit of $\mathrm{v}$. If the supply relationship between the firm and the supplier is severed, the supplier's next best market is less profitable than if no such supply relationship had been established. We denote the supplier's net profits in the absence of a supply relationship by $\mathrm{v}_{\mathrm{o}}$, where $v_{\mathrm{o}}>\mathrm{v}$. Finally, although we model the stakeholder as a single supplier, it could also be thought of as a representative of stakeholders in general.

\subsection{Information}

At date 0 , the probability of financial distress (1- $\theta)$ is common knowledge, as are all contractual agreements signed at date 0 . At date 1 , both the firm and the bank, but not the supplier, observe whether the firm is healthy or distressed. Thus, the bank is a fully informed investor, but neither the supplier nor any potential outside lender can observe the firm's actual financial condition.

This information structure captures two essential ideas, both of which derive from the costs of producing information. First, a bank that has evaluated a firm's initial prospects and maintained an ongoing relationship with the firm is likely to be at an informational advantage compared to other potential lenders. Second, although the firm's non-equity stakeholders have a substantial interest in 
information about the firm's prospects, having a single agent, such as a bank, produce information about the firm can reduce the costs of information production. Whether it is efficient for the supplier to delegate information production to the bank, and whether it is efficient for the firm to permit a single lender to have an informational monopoly will depend, in turn, on the types of contracts that the firm, the bank, and the supplier sign. ${ }^{15}$

\subsection{Contracts}

\section{Contracts between the firm and the supplier}

At date 0 , the firm and supplier sign a contract that commits the firm to pay a price $\mathrm{m}_{\mathrm{o}} \underline{\text { at date } 2}$ for the input. Thus, we assume: (i) that the supplier cannot be paid up-front for the promised input and (ii) that the supplier has a fixed-price claim on the firm--the firm and the supplier cannot write explicit revenue contingent contracts at date 0 . By mutual consent, however, the firm and the supplier may renegotiate the contract price at date 1 . Recognizing the possibility that the final contract price might differ from the original contract price $\left(\mathrm{m}_{\mathrm{o}}\right)$, we write the contract price that prevails when the firm is type $\mathrm{t}_{\mathrm{j}}$ as $\mathrm{m}_{\mathrm{j}}, \mathrm{j}=\mathrm{h}, \mathrm{d}$.

Although we do not derive explicitly the optimal contractual claim between the firm and the supplier, our supply contract is intended to capture the main features of many real world supply relationships. Supply prices are typically inflexible in most states of the world, because of the high costs of writing detailed state-contingent contracts. At the same time, contracts are not totally inflexible and may be renegotiated when business conditions change significantly--such as when the firm enters into a state of financial distress. Our assumption that payments to suppliers can be made only at date 2 is a stylized description of a typical relationship between a firm and its trade creditors--where payments to suppliers are financed out of the revenues from firm sales. ${ }^{16}$

\section{Contracts between the firm and the bank}


The bank and the firm are assumed to sign a funding commitment at date 0 . The contract states that the firm may draw down up to X dollars at date 1, subject to the bank's approval. We permit the bank's claim to be a mixture of debt and equity. That is, the funding commitment specifies a financial claim for the bank, $\left\{a_{0}, D_{o}\right\}$, where $a_{o}$ (the bank's equity share) is the bank's contractual share of the firm's date 2 profits and $D_{o}$ is the face value of the bank's debt claim, assuming that the firm draws down the $\mathrm{X}$ dollars and that it is not liquidated at date 1 . Contracts may be renegotiated by mutual consent at date 1. We write the bank's claim when the firm is type $t_{j}$ as $\left\{a_{j}, D_{j}\right\}$.

\section{The relative priority of the bank's and the supplier's claims}

The results in our paper that suggest a positive role for routine bank equity holdings in the firm depend on the assumption that the bank cannot credibly subordinate its debt claim to that of the supplier. Thus, for much of the paper, we view bank equity holdings as the only credible means for the bank to subordinate a portion of its total claim to that of the supplier. Our motivation for this assertion is twofold.

First, as an informed insider, the bank will typically learn about any deterioration in the firm's financial condition before uninformed stakeholders. This gives the bank ample opportunity to take collateral or to perfect a preexisting claim on assets out of view and out of the control of the firm's longtime suppliers and customers. ${ }^{17}$ Second, although we have modeled the supply contract as a binding legal contract with a single contractual price, we might just as well view it as part of an implicit contingent contract with a higher price when the firm is healthy and a lower price when the firm is distressed. As long as the supplier can differentiate healthy from distressed firms--and the role of the bank in our model is to communicate this information to the supplier--then such implicit contracts will often be feasible. In this interpretation, the bank cannot credibly subordinate its own explicit contractual debt claim to that of stakeholders, who have implicit promises of dubious standing in court.

\subsection{Contract renegotiations}


Contracts between the firm, the bank, and the supplier may be renegotiated at date 1. Our stylized model of contract renegotiations is intended to capture two main ideas. The first idea is that the bank and the firm--as informed agents--might have opportunities to strike a deal to expropriate uninformed stakeholders and that the actual deliberations may be unobservable by stakeholders. Thus, the outcome of negotiations between the firm and the bank--for example, a proposal to restructure contracts--may be the supplier's only information to help judge the actual content of the negotiations. The second idea is that the bank's key role in financial distress gives it bargaining power that it does not have when the firm is healthy. Thus, both the firm and stakeholders are at a bargaining disadvantage vis a vis the bank when the firm is financially distressed and contracts must be restructured for efficient production.

We assume that negotiations at date 1 take place sequentially, as pictured in Figure 2. In stage 1 , the firm and the bank negotiate over the bank's financial claim. Then, in stage 2 , the firm/bank coalition negotiates with the supplier over the price of the input. In stage 1, the bank makes a single offer to the firm, which the firm may accept or refuse. If the firm refuses, the initial contract terms remain in effect. In either case, the firm and the bank then decide whether they wish to continue production or to liquidate the firm. If the firm and the bank reach agreement to continue production, they announce their contractual agreement to the supplier. This final agreement is the only aspect of stage 1 negotiations that can be observed by the supplier. In stage 2 the firm/bank coalition makes a single offer to the supplier, which it may accept or reject. If it rejects the offer, the original contract terms remain in force. At that time, all agents--the firm, the supplier, and the bank--decide whether they wish to continue production. ${ }^{18}$

\subsection{Parametric restrictions}

First, we assume that liquidation at date 1 is never efficient ex post,

$$
p_{d} R_{g}+\left(1-p_{d}\right)\left[R_{b}-B\right]>X+c+v+w
$$

The left hand side of inequality (1) denotes the expected date 2 revenues for a financially distressed firm-- 
assuming that the firm defaults when revenues are low. (Thus, the left-hand side assumes the worst possible date 2 outcome). The right-hand side of (1) is the sum of the additional funds needed at date 2 (X), the supplier's costs of supplying the input $(\mathrm{c}+\mathrm{v})$--which includes both the direct production costs and the forgone profits in the alternative market, and the firm owners' opportunity cost--their income in alternative employment (w).

Second, we assume that the lowest possible date 2 revenues are too low to cover the supplier's costs of supplying the input (evaluated at date 0 ),

$$
\mathrm{R}_{\mathrm{b}}<\mathrm{c}+\mathrm{v}_{\mathrm{o}}
$$

As we shall see, inequality (2) implies that stakeholders must make concessions to avoid inefficiencies when the firm enters financial distress.

\subsection{Profit functions}

It is convenient to think of the second stage of contract renegotiations as a game in which the bank announces the firm's type to the supplier at date 1. The following profit functions refer to each agent's expected date 2 payoff when the bank states that the firm is type $\mathrm{i}$ and the firm is actually type $\mathrm{j}$. We denote the firm's total fixed claims by

$$
\mathrm{F}_{\mathrm{i}} \equiv \mathrm{m}_{\mathrm{i}}+\mathrm{D}_{\mathrm{i}}
$$

and we use the indicator function to denote whether the firm can meet its fixed claims at date 2, that is,

$$
\begin{aligned}
\delta_{\mathrm{ki}}= & 1 \text { if } \mathrm{R}_{\mathrm{k}} \geq \mathrm{F}_{\mathrm{i}}, \\
& 0 \text { if } \mathrm{R}_{\mathrm{k}}<\mathrm{F}_{\mathrm{i}}, \quad \mathrm{k}=\mathrm{g}, \mathrm{b}, \mathrm{i}=\mathrm{h}, \mathrm{d} .
\end{aligned}
$$

If the firm continues production at date 1 , then its expected payoff is,

$$
\pi^{\mathrm{f}}(\mathrm{i} \mid \mathrm{j})=\mathrm{p}_{\mathrm{j}}\left(1-\mathrm{a}_{\mathrm{i}}\right)\left[\mathrm{R}_{\mathrm{g}}-\mathrm{F}_{\mathrm{i}}, 0\right]^{+}+\left(1-\mathrm{p}_{\mathrm{j}}\right)\left(1-\mathrm{a}_{\mathrm{i}}\right)\left[\mathrm{R}_{\mathrm{b}}-\mathrm{F}_{\mathrm{i}}, 0\right]^{+}
$$

and if the firm is liquidated its expected payoff is $\mathrm{w}$.

If the firm continues production at date 1 , and if the bank's fixed claim has priority over the 
supplier's claim, the bank's expected payoff (gross of its funding costs) is,

$$
\begin{aligned}
\pi^{\mathrm{b}}(\mathrm{i} \mid \mathrm{j})= & \mathrm{p}_{\mathrm{j}}\left(\mathrm{a}_{\mathrm{i}}\left[\mathrm{R}_{\mathrm{g}}-\mathrm{F}_{\mathrm{i}}, 0\right]^{+}+\delta_{\mathrm{gi}} \mathrm{D}_{\mathrm{i}}+\left(1-\delta_{\mathrm{gi}}\right)\left[\mathrm{R}_{\mathrm{g}}-\mathrm{B}\right]\right) \\
& +\left(1-\mathrm{p}_{\mathrm{j}}\right)\left(\mathrm{a}_{\mathrm{i}}\left[\mathrm{R}_{\mathrm{b}}-\mathrm{F}_{\mathrm{i}}, 0\right]^{+}+\delta_{\mathrm{bi}} \mathrm{D}_{\mathrm{i}}+\left(1-\delta_{\mathrm{bi}}\right)\left[\mathrm{R}_{\mathrm{b}}-\mathrm{B}\right]\right) .
\end{aligned}
$$

The third expressions on both the top and bottom line incorporate the priority assumption. If the firm defaults at date 2, the bank captures all of the revenues net of the deadweight bankruptcy costs, $\left[R_{k}-B\right]$, when its claim has higher priority than the supplier's. If the supplier's claim has priority over the bank's fixed claim, the bank's payoff is,

$$
\begin{aligned}
\pi^{\mathrm{b}}(\mathrm{i} \mid \mathrm{j})= & \mathrm{p}_{\mathrm{j}}\left(\mathrm{a}_{\mathrm{i}}\left[\mathrm{R}_{\mathrm{g}}-\mathrm{F}_{\mathrm{i}}, 0\right]^{+}+\delta_{\mathrm{gi}} \mathrm{D}_{\mathrm{i}}+\left(1-\delta_{\mathrm{gi}}\right)\left[\mathrm{R}_{\mathrm{g}}-\mathrm{B}-\mathrm{m}_{\mathrm{i}}, 0\right]^{+}\right) \\
& +\left(1-\mathrm{p}_{\mathrm{j}}\right)\left(\mathrm{a}_{\mathrm{i}}\left[\mathrm{R}_{\mathrm{b}}-\mathrm{F}_{\mathrm{i}}, 0\right]^{+}+\delta_{\mathrm{bi}} \mathrm{D}_{\mathrm{i}}+\left(1-\delta_{\mathrm{bi}}\right)\left[\mathrm{R}_{\mathrm{b}}-\mathrm{B}-\mathrm{m}_{\mathrm{i}}, 0\right]^{+}\right) .
\end{aligned}
$$

Again, the third expressions on both lines incorporate the priority assumption. If the firm defaults at date 2 , the bank receives a return $\left[\mathrm{R}_{\mathrm{k}}-\mathrm{B}-\mathrm{m}_{\mathrm{i}}\right]$ only if revenues net of bankruptcy costs exceed the supplier's claim. ${ }^{19}$ If the firm is liquidated, the bank's payoff is zero.

If the firm continues production, and if the supplier's claim is subordinated to the bank's claim, the supplier's expected payoff is,

$$
\begin{aligned}
\pi^{\mathrm{s}}(\mathrm{i} \mid \mathrm{j})= & \mathrm{p}_{\mathrm{j}}\left(\delta_{\mathrm{gi}} \mathrm{m}_{\mathrm{i}}+\left(1-\delta_{\mathrm{gi}}\right)\left[\mathrm{R}_{\mathrm{g}}-\mathrm{B}-\mathrm{D}_{\mathrm{i}}, 0\right]^{+}\right) \\
& +\left(1-\mathrm{p}_{\mathrm{j}}\right)\left(\delta_{\mathrm{bi}} \mathrm{m}_{\mathrm{i}}+\left(1-\delta_{\mathrm{bi}}\right)\left[\mathrm{R}_{\mathrm{b}}-\mathrm{B}-\mathrm{D}_{\mathrm{i}}, 0\right]^{+}\right)-\mathrm{c},
\end{aligned}
$$

and if the bank's fixed claim is subordinated, the supplier's expected payoff is,

$$
\begin{aligned}
\pi^{\mathrm{s}}(\mathrm{i} \mid \mathrm{j})= & \mathrm{p}_{\mathrm{j}}\left(\delta_{\mathrm{gi}} \mathrm{m}_{\mathrm{i}}+\left(1-\delta_{\mathrm{gi}}\right)\left[\mathrm{R}_{\mathrm{g}}-\mathrm{B}\right]\right) \\
& +\left(1-\mathrm{p}_{\mathrm{j}}\right)\left(\delta_{\mathrm{bi}} \mathrm{m}_{\mathrm{i}}+\left(1-\delta_{\mathrm{bi}}\right)\left[\mathrm{R}_{\mathrm{b}}-\mathrm{B}\right]\right)-\mathrm{c} .
\end{aligned}
$$

If the firm is liquidated, then the supplier produces elsewhere and receives $\mathrm{v}$.

Finally we denote the profit functions when the bank is truthful by:

$$
\pi^{\mathrm{n}}(\mathrm{j}) \equiv \pi^{\mathrm{n}}(\mathrm{j} \mid \mathrm{j}), \quad \mathrm{n}=\mathrm{f}, \mathrm{b}, \mathrm{s}, \text { and } \mathrm{j}=\mathrm{h}, \mathrm{d} \text {. }
$$




\section{The structure of the bank's optimal claim}

In this section we show how the bank's financial claim can be structured to facilitate the efficient restructuring of claims when the firm is in financial distress. The underlying problem is that the firm and the bank have an incentive to form a coalition to expropriate the uninformed supplier. There are two potential conflicts of interest between the firm/bank coalition and the supplier to overcome.

First, the informed bank has an incentive to collude with a healthy firm to seek unnecessary concessions from suppliers. But the structure of the bank's financial claim on a distressed firm can be designed to prevent the possibility of collusion in healthy states. In essence, the bank and the firm use contracts to create a conflict of interest between themselves over the division of the surplus expropriated from the supplier. This contractually created conflict of interest between the bank and the firm permits the bank to signal credibly that the firm and bank are not seeking unnecessary concessions. More specifically, we show that the bank can establish the need for concessions in one of two ways. Its equity claim on the distressed firm must be sufficiently small--that is, below a ceiling level $\left(\mathrm{a}_{\mathrm{d}}^{\mathrm{c}}\right)$---or else it must be sufficiently large--that is, above some floor $\left(a_{d}^{f}\right)$, where $a_{d}^{f}>a_{d}^{c}$. Said differently, the bank's equity share on the distressed firm must lie outside the interval $\left(a_{d}^{c}, a_{d}^{f}\right)$.

Second, the bank may have an incentive to collude with the distressed firm to claim that the firm is actually healthy, despite the presence of deadweight bankruptcy costs. This conflict arises when the bank cannot credibly subordinate its debt claim to that of the supplier. To ensure that the bank and the distressed firm have an incentive to seek a full restructuring of claims, the bank's claim on the healthy firm--its initial contractual claim--cannot be a pure debt claim.

We proceed in two steps. In Section 2.1, we derive restrictions on the bank's financial claim on the distressed firm, which prevent the firm and the bank from seeking unnecessary concessions from stakeholders (Proposition 1). The results in Proposition 1 hold for all parameter values and are 
independent of any assumptions about the relative priority of the bank's and supplier's fixed claims. In Section 2.3, we derive restrictions on the structure of the bank's initial financial claim, which ensure that the distressed firm and the bank will not claim falsely that the firm is healthy (Propositions 2 and 3).

\subsection{Credibility and the bank's claim on the distressed firm}

We begin with a lemma that states that the first-best outcome--the outcome that maximizes the joint profits of the firm, the bank, and the supplier--requires the restructuring of the supplier's claim when the firm is in financial distress. The formal proofs of this lemma and all following results are placed in the appendix.

Lemma 1: Joint profits are maximized only if:

$$
\mathrm{m}_{\mathrm{h}}>\mathrm{R}_{\mathrm{b}}>\mathrm{m}_{\mathrm{d}} \text {. }
$$

Intuitively, the supplier will not enter into a supply relationship unless its expected profits are greater than $\mathrm{v}_{\mathrm{o}}$, which implies that $\mathrm{m}_{\mathrm{h}}>\mathrm{c}+\mathrm{v}_{\mathrm{o}}>\mathrm{R}_{\mathrm{b}}$, the second inequality following from parametric restriction (2). But this means that the distressed firm will be unable to cover its fixed payments at date 2 with probability $\left(1-p_{d}\right)$ unless the supplier agrees to a concessionary claim in financial distress, that is, $m_{d}<R_{b}$. If the supplier will not restructure its claim in financial distress, then, depending on the value of the firm owners' outside employment opportunities (w), one of two inefficiencies will arise. If the firm owners' outside employment opportunities are sufficiently profitable, the firm owners will refuse to continue production--an inefficient outcome by inequality (1)--unless the supplier offers concessions. If the firm owners' outside employment opportunities are relatively unprofitable, both the bank and the distressed firm might be willing to continue production even if the supplier refuses to make concessions. However, this will lead to excessive deadweight bankruptcy costs, which raise expected input and funding 
costs and reduce the firm's date 0 expected profits.

In light of Lemma 1, we focus our attention on separating equilibria in which the supplier is willing to accept a concessionary supply price when the firm enters financial distress. ${ }^{20}$ The following proposition states our first main result, the necessary restrictions on the bank's financial claim on the distressed firm to ensure that the supplier will make concessions. It also gives a partial description of the pure strategy sequential equilibrium contractual outcomes. Since Proposition 1 holds whatever the relative priority of claims, the payoff functions can refer to either the case where the bank's claim has higher priority than the supplier's or vice versa.

Proposition 1: The supplier will accept concessions from the distressed firm only if the bank holds a contractual claim in financial distress $\left\{a_{d}, D_{d}\right\} \neq\left\{a_{0}, D_{o}\right\}$, in which the bank's equity share $a_{d}$ falls outside the interval $\left(\mathrm{a}_{\mathrm{d}}^{\mathrm{c}}, \mathrm{a}_{\mathrm{d}}^{\mathrm{f}}\right)$, where,

$$
\mathrm{a}_{\mathrm{d}}^{\mathrm{c}} \equiv\left[\frac{\pi^{\mathrm{b}}(\mathrm{h})-\pi^{\mathrm{b}}(\mathrm{d})}{\left(\mathrm{p}_{\mathrm{h}}-\mathrm{p}_{\mathrm{d}}\right)\left(\mathrm{R}_{\mathrm{g}}-\mathrm{R}_{\mathrm{b}}\right)}\right],
$$

and,

$$
a_{d}^{f} \equiv a_{d}^{c}+\left[\frac{\pi^{s}(h)-\left(m_{d}-c\right)}{\left(p_{h}-p_{d}\right)\left(R_{g}-R_{b}\right)}\right]>a_{d}^{c} .
$$

In financial distress, the renegotiated price for the supplier is,

$$
\mathrm{m}_{\mathrm{d}}=\mathrm{c}+\mathrm{v}
$$

and $\left\{a_{d}, D_{d}\right\}$ satisfies,

$$
\pi^{\mathrm{f}}(\mathrm{d})=[\mathrm{w}, 0]^{+} \text {, and } \pi^{\mathrm{b}}(\mathrm{d})=\mathrm{p}_{\mathrm{d}} \mathrm{R}_{\mathrm{g}}+\left(1-\mathrm{p}_{\mathrm{d}}\right) \mathrm{R}_{\mathrm{b}}-\mathrm{m}_{\mathrm{d}}-\pi^{\mathrm{f}}(\mathrm{d})
$$

The initial contract is not renegotiated when the firm is healthy, that is:

$$
\left\{\mathrm{a}_{\mathrm{h}}, \mathrm{D}_{\mathrm{h}}, \mathrm{m}_{\mathrm{h}}\right\}=\left\{\mathrm{a}_{\mathrm{o}}, \mathrm{D}_{\mathrm{o}}, \mathrm{m}_{\mathrm{o}}\right\}
$$


The intuition behind the separating equilibrium described in (6)-(8) is straightforward. The supplier will be unwilling to make price concessions to the distressed firm unless the bank's claim on the distressed firm differs from its claim on the healthy firm. Since the bank's claim signals the underlying state in a separating equilibrium, a supplier confronted with a demand for concessions from a firm that it knows to be healthy will insist on its initial contractual price. As long as it does so, there are no rents to be shared between the healthy firm and the bank; and since the healthy firm can, in fact, continue without concessions, it will also insist on its initial contractual agreement with the bank. Thus, the initial contracts remain in force when the firm is healthy, as stated in (8).

However, when the firm is distressed, neither the firm nor the supplier can insist on its initial contract. Given our bargaining structure, the firm/bank coalition will demand that the supplier accept a price $\left(\mathrm{m}_{\mathrm{d}}\right)$ that leaves it indifferent between producing for the firm and severing the supply relationship; thus, $m_{d}=c+v$, as stated in (6). The bank, which has an enhanced bargaining position when the firm is in distress, permits the firm's owners to retain just enough equity to keep them indifferent between continuing production and liquidation (in which case they could earn income w outside the firm), as stated in (7).

But how can the supplier be sure that the demand for concessions has not come from a healthy firm colluding with the bank to extract rents at the supplier's expense? The key is for the bank to hold a claim on the distressed firm that creates a conflict between the bank and the healthy firm over the distribution of any rents extracted from the supplier. The requirement that the bank's equity claim in financial distress fall outside the interval $\left(\mathrm{a}_{\mathrm{d}}^{\mathrm{c}}, \mathrm{a}_{\mathrm{d}}^{\mathrm{f}}\right)$ provides two alternative contractual restrictions that create such a conflict and prevent the coalition from forming. The first alternative--a ceiling on the bank's equity share $\left(\mathrm{a}_{\mathrm{d}}^{\mathrm{c}}\right)$--guarantees that the bank finds it unprofitable to collude with the healthy firm against the supplier. The second alternative--a floor under the bank's equity share $\left(a_{d}^{\mathrm{f}}\right)$--guarantees that the 
healthy firm finds it unprofitable to collude with the bank. ${ }^{21}$ The following discussion of the bank's and the healthy firm's incentives to collude is illustrated in Figure 3.

The ceiling $\left(\mathrm{a}_{\mathrm{d}}^{\mathrm{c}}\right)$ comes directly from the bank's truth-telling constraint:

$$
\pi^{b}(h) \geq \pi^{b}(d \mid h)=\pi^{b}(d)+a_{d}\left(p_{h}-p_{d}\right)\left(R_{g}-R_{b}\right)
$$

which says that when the firm is healthy the bank prefers its initial contractual claim to its concessionary claim.

Intuitively, an equity share gives the bank a residual claim on the firm's profits, which would increase with a concessionary reduction in the supplier's price. If the bank were permitted too large an equity share in the distressed firm, it would wish to collude with the healthy firm to extract rents from the supplier. Further, as long as the bank's equity share in the distressed firm is not so large that it would capture a disproportionate share of the rents, the healthy firm would also find it profitable to collude against the supplier.

To see that such a coalition would form if the bank's equity claim on the distressed firm falls within the interval $\left(a_{d}^{c}, a_{d}^{f}\right)$, note that the healthy firm would prefer its concessionary equity share $\left(1-a_{d}\right)$ to its initial equity share $\left(1-\mathrm{a}_{\mathrm{o}}\right)$ as long as,

$$
\pi^{\mathrm{f}}(\mathrm{h})<\pi^{\mathrm{f}}(\mathrm{d} \mid \mathrm{h})
$$

which can be rewritten as a restriction on the size of the bank's equity claim: ${ }^{22}$

$$
a_{d}<\frac{\left[\pi^{b}(h)-\pi^{b}(d)\right]+\left[\pi^{s}(h)-\left(m_{d}-c\right)\right]}{\left(p_{h}-p_{d}\right)\left(R_{g}-R_{b}\right)}=a_{d}^{c}+\left[\frac{\pi^{s}(h)-\left(m_{d}-c\right)}{\left(p_{h}-p_{d}\right)\left(R_{h}-R_{d}\right)}\right]
$$

So, if the bank's claim on the distressed firm exceeded the ceiling $\left(\mathrm{a}_{\mathrm{d}}^{\mathrm{c}}\right)$, both the bank and the firm would prefer to claim that the firm was in a distressed state and share the rents expropriated from the supplier for $\mathrm{a}_{\mathrm{d}}$ over the interval, 


$$
a_{d} \in\left(a_{d}^{c}, a_{d}^{c}+\left[\frac{\pi^{s}(h)-\left(m_{d}-c\right)}{R_{h}-R_{d}}\right]\right) .
$$

Of course, a rational supplier would always refuse to make price concessions demanded by a firm/bank coalition in which the bank holds an equity claim on the interval defined in (12).

Simply reversing inequality (10) yields the second alternative restriction on the bank's claim, the floor $\left(a_{d}^{f}\right)$ defined in (5). If the bank takes a sufficiently large equity share when the firm is in financial distress, a healthy firm would always prefer the initial contract to forming a coalition with the bank to expropriate the supplier. Intuitively, when the bank's equity share in financial distress is very large, the bank would capture a disproportionate share of any rents captured from the supplier, so the healthy firm's profits are higher under the original contract and no coalition can form.

The main empirical prediction of this section is that banks face potentially severe restrictions on their ability to take equity positions in distressed firms in the presence of other fixed claimants. ${ }^{23}$ This is consistent with the emerging literature on financial distress in the U.S., which suggests that conflicts among fixed claimants--rather than regulatory restrictions--are the main constraint on bank equity positions in distressed restructurings. It is also consistent with evidence from Germany that banks seldom take equity positions in financially distressed firms. ${ }^{24}$

\subsection{The structure of the bank's claim and uninformed claimants: related literature}

Ours is a novel signaling model with two informed agents--the firm and the bank--in which the signal about the firm's type is the outcome of bargaining between the informed agents, and in which both the firm and the bank must agree to send a particular signal. Although the firm and the bank potentially have a common interest in seeking concessions from the supplier, they also have a conflict of interest concerning the distribution of the surplus. The bank's stronger bargaining position when the firm is truly financially distressed (compared to when the firm is healthy) restricts the gains that the healthy firm/ bank 
coalition can achieve at the supplier's expense by lying. This follows since any proposal must mimic that which would arise in equilibrium were the firm truly distressed. Since the healthy firm and the bank's respective gains depend on the structure of the bank's financial claim on the distressed firm, this claim can be designed to make it impossible for a coalition to form when the firm is healthy, as described above.

Brown, James and Mooradian (BJR) (1993) and Heinkel and Zechner (H\&Z)(1993) also consider models in which firms have incentives to seek unnecessary concessions from uninformed creditors. In BJR's model of public restructurings, a distressed firm/bank coalition offers new securities to uninformed bondholders, which supports a signaling equilibrium in which better firms offer senior debt and worse firms offer equity. Unlike our model, the firm in BJR is assumed to be in default on its debt obligations from the outset, and the bank and the firm are assumed to maximize joint profits; that is, the existence of the firm/bank coalition--with some distribution of bargaining power determined by the event of default--is also given from the outset. In our model, only the distressed firm requires concessions from the supplier, and our central question is how contracts can be designed to prevent collusion between the firm and the bank.

In a model without an informed creditor, H\&Z show that for some parametric restrictions the firm can assure uninformed bondholders that they are seeking only necessary concessions by swapping convertible debt for straight debt, a possibility we rule out by assumption. Although H\&Z's solution may be attractive as a means of restructuring the firm's debt, it is less so when the contracts that must be restructured are those of the firm's suppliers and customers. When an individual stakeholder's contribution to firm profitability is difficult to measure, and when total firm profitability depends upon managerial decisions as well as the quality of inputs provided by other suppliers and purchasing decisions made by other customers, stakeholders may be loath to accept payments based on firm profits. These 
appropriation problems do not arise for bondholders, who do not maintain a continuing productive relationship with the firm.

In Admati and Pfleiderer's (A\&P) (1994) model of a venture capitalist, the optimal venture capital contract requires uninformed outside investors to contribute a share of the subsequent funding for a project initially financed by an informed investor. The venture capitalist's fixed share contract ensures not only that interim investment incentives are correct but also that the outside investors pay a fair price for their claims--as long as they refuse to invest when they observe a revision of the original contract between the firm and the venture capitalist. Thus, renegotiation never occurs; in fact, any attempt to renegotiate the initial contract would lead outside investors to shun investment in the firm. Unlike our stakeholders, A\&P's uninformed investors have no initial investment in the firm. In our model, stakeholders' initial willingness to engage in a supply relationship requires an enforceable initial contract, and the need to reduce fixed claims in financial distress ensures that renegotiation actually occurs. Thus, we cannot rely on a non-negotiable contract as a means of ensuring that uninformed stakeholders are not exploited.

\subsection{Credibility and the bank's claim on the healthy firm}

The separating equilibrium described in Proposition 1 is feasible only if the supplier has no reason to be suspicious of a bank's statement that the firm is healthy. And if the bank can credibly subordinate its own debt claim to the supplier's claim, the bank has a simple way to signal to the supplier that it would never falsely state that a distressed firm was healthy. Specifically, the bank can be a pure debtholder with a claim strictly subordinate to the supplier. In this case, a false statement that the distressed firm was healthy would lead to a high probability that the firm will default on its fixed claims, and the supplier would be paid out of the firm's revenues before the bank. Thus, the bank would have nothing to gain by 
denying that the firm was in distress.

Since Proposition 1 has already established that the bank cannot form a coalition with the healthy firm if it holds a pure debt claim when the firm is in distress--and since the restrictions on the bank's financial claim on the distressed firm do not depend on the relative priority of the bank's debt claim on the distressed firm--we have the following proposition:

Proposition 2: No bank/firm coalition to expropriate the supplier can form if the bank holds a pure debt claim, as long as the bank's initial contractual debt claim $\left(\mathrm{D}_{\mathrm{o}}\right)$ is subordinated to all other fixed claims.

However, recognizing the bank's difficulties in subordinating its debt claim to all stakeholders, a bank equity share in the firm may serve a positive function under some conditions, as the following proposition states:

Proposition 3: Assume that the bank's debt claim has priority over the supplier's claim. When firm owners' wage in alternative employment, w, is below a critical value w*--to be defined below--the distressed firm would always seek to misrepresent itself as a healthy firm. Further, when

$$
\left(m_{d}-p_{d} m_{o}\right)-\left(1-p_{d}\right) B>0
$$

then the bank will reveal truthfully the distressed firm's financial condition only if the bank's initial claim includes some equity, that is, $\left\{\mathrm{a}_{\mathrm{o}}>0, \mathrm{D}_{\mathrm{o}} \geq 0\right\}$.

Intuitively, when the firm is in financial distress there is a substantial probability of default--(1- 
$\mathrm{p}_{\mathrm{d}}$ )--if the supplier's claims are not renegotiated. When the deadweight bankruptcy costs are not too large, a bank with no initial equity claim and an initial debt claim, $D_{o}>R_{b}-B$, can often profitably expropriate the supplier by claiming falsely that the distressed firm is healthy. ${ }^{25,26}$ The bank would induce the supplier to produce the input at the original supply price, while the probability that the supplier will actually recover any payment is small--because of the high probability of default and the banker's higher priority in the event of default. Thus, with a high probability the bank captures all of the firm revenues (net of the deadweight bankruptcy costs) and the supplier is effectively expropriated.

Condition (13) is a necessary condition for the distressed firm and bank to collude profitably and misrepresent the firm as healthy. The condition shows the net gains to the distressed firm/bank coalition from expropriating the supplier in this way. The coalition avoids paying the supplier its restructured wage, $m_{d}$, but it must weigh against this gain the expected deadweight bankruptcy costs, $\left(1-p_{d}\right) B$, and the expected payments to the supplier under the original contract, $\mathrm{p}_{\mathrm{d}} \mathrm{m}_{\mathrm{o}}$.

The distressed firm would agree to form a coalition with the bank as long as its payoff under a full restructuring of claims is sufficiently low. Specifically, the distressed firm would prefer to collude with the bank to expropriate the supplier as long as,

$$
\pi^{\mathrm{s}}(\mathrm{h} \mid \mathrm{d})=\mathrm{p}_{\mathrm{d}}\left(1-\mathrm{a}_{\mathrm{o}}\right)\left[\mathrm{R}_{\mathrm{g}}-\mathrm{m}_{\mathrm{o}}-\mathrm{D}_{\mathrm{o}}\right] \geq \pi^{\mathrm{s}}(\mathrm{d})=[0, \mathrm{w}]^{+}
$$

Note, that since $m_{o}>R_{b}$, the firm defaults and receives no payoff with probability $\left(1-p_{d}\right)$. Since the size of the bank's and the supplier's initial contractual claims are determined by their date 0 participation constraints, and since a defaulting firm cares nothing about the relative priority of the bank and supplier's respective claims, the distressed firm is concerned only about the sum of the initial contractual payments to the bank and the supplier $\left(m_{o}+a_{o}\left[R_{g}-m_{o}-D_{o}\right]+D_{o}\right)$. Thus, the distressed firm's payoff under collusion is unaffected by the structure of the bank's claim. Using the bank and the supplier's date 0 participation constraints and rearranging, condition (14) can be rewritten, 


$$
\mathrm{w}^{*} \equiv\left[\frac{\mathrm{p}_{\mathrm{d}}}{\mathrm{p}_{\mathrm{h}} \theta+\mathrm{p}_{\mathrm{d}}(1-\theta)}\right]\left[\mathrm{E}\left(\mathrm{R}_{\mathrm{k}}\right)-\theta\left(1-\mathrm{p}_{\mathrm{h}}\right) \mathrm{B}-\left(\mathrm{c}+\mathrm{v}_{\mathrm{o}}\right)-\left(\mathrm{X}_{\mathrm{o}}+\mathrm{X}\right)\right] \geq[0, \mathrm{w}]^{+},
$$

where,

$$
\mathrm{E}\left(\mathrm{R}_{\mathrm{k}}\right) \equiv\left(\theta \mathrm{p}_{\mathrm{h}}+(1-\theta) \mathrm{p}_{\mathrm{d}}\right) \mathrm{R}_{\mathrm{g}}+\left(\theta\left(1-\mathrm{p}_{\mathrm{h}}\right)+(1-\theta)\left(1-\mathrm{p}_{\mathrm{d}}\right)\right) \mathrm{R}_{\mathrm{b}}
$$

Thus, as long as the firm's owners have only relatively unprofitable opportunities outside the firm--or if they benefit from substantial control rents--the distressed firm will be willing to collude with the bank to expropriate the supplier.

Under these conditions, the supplier must rely upon the bank to reveal truthfully whether the firm is distressed. Here, a large enough initial bank equity claim allows the bank to subordinate enough of its total claim to that of the supplier to ensure that it will not collude with the distressed firm. Specifically, from the bank's truth-telling condition,

$$
\pi^{\mathrm{b}}(\mathrm{d}) \geq \pi^{\mathrm{b}}(\mathrm{h} \mid \mathrm{d})
$$

we can determine the minimum initial equity stake that would guarantee that the bank will not collude with the distressed firm:

$$
a_{o} \geq \frac{\pi^{b}(h)-\pi^{b}(d)}{\left(p_{h}-p_{d}\right)\left(R_{g}-m_{o}-D_{o}\right)}+\frac{\left[R_{b}-B, D_{o}\right]^{-}-D_{o}}{R_{g}-m_{o}-D_{o}}
$$

\subsection{Other factors affecting the structure of the bank's initial claim}

To this point, our model yields limits on bank equity shares in financially distressed firms and provides conditions in which banks will optimally hold at least some equity under normal financial conditions. Yet it provides no upper bound on the bank's equity share under normal conditions. Strictly speaking, our bank might hold a pure equity claim as long as the firm is healthy, a possibility clearly 
inconsistent with prevailing bank practices anywhere. However, our simple model can be extended to ensure that the bank will optimally hold a debt claim when the firm is financially healthy.

In an earlier version of this paper (Berlin, John and Saunders (1993)), we examine an extension in which the firm's ultimate probability of financial distress is determined by its choice between a safe and a risky project and in which the bank can exercise a veto over the firm's project choice through its refusal to lend initial funds. In that model, we show that the bank's optimal initial claim will always include a strictly positive amount of debt. Intuitively, a pure equity claim would give the bank an excessive preference for projects that shift risks to the firm's other fixed claimants. ${ }^{27}$

Another potential difficulty with our model is our assumption that banks may write lending contracts that specify debt and equity shares. The available evidence suggests that banks initially accumulate equity stakes in a less systematic way than our model would predict. ${ }^{28}$ We view our model as a stylization of a world in which banks may hold continuing equity positions, unconstrained by regulatory restrictions. Although the initial reason for a bank equity position may offer evidence about its function, the bank may maintain an equity stake for reasons--perhaps multiple reasons--unrelated to its origin. Nonetheless, the fact that banks do not write explicit debt-equity contracts under routine conditions suggests an underlying preference for debt claims not captured by our model.

\subsection{Optimal priority of the bank's claim: related literature}

Other recent contributions have predictions about the optimal priority of an informed lender's claim. Some papers offer arguments that the informed investor's optimal claim is subordinate to uninformed creditors. For example, Fama (1990) argues that an informed bank's optimal claim is a subordinated debt claim, so that the bank can make credible statements about the firm's creditworthiness to uninformed stakeholders. Fama doesn't examine contract negotiations per se and he makes no attempt to formalize or prove his claim. In a sense, our model may be viewed as one possible formalization and 
elaboration of Fama's claim. Rajan (1992) also argues that the bank's claim should be subordinated, to reduce its bargaining power when contracts are renegotiated and thereby to increase the borrower's initial effort. Unlike our model, the relative priority of the bank's debt plays no role in conveying information to other creditors in Rajan. Similarly, in Brown, James, and Mooradian's (1993) model of private restructurings--in which the bank accepts subordinated claims only when firms' prospects are truly bad-the structure of the bank's claim is not used to affect its ability to convey credible information to uninformed creditors.

Other papers predict that the optimal claim for an informed lender has higher priority than uninformed creditors. In Diamond (1993), where banks have incentives to liquidate excessively (because of the existence of large non-appropriable control rents), a higher priority claim permits the bank to expropriate other creditors ex post and to internalize as much of the appropriable firm value as possible. In Berlin and Mester (1992) and Gorton and Kahn (1993), a higher priority bank claim enhances the bank's threat to liquidate the firm in the event of default, which reduces the firm's incentives to take excessive risks. In each of these papers, the central question in contract design is improving the efficiency of the informed lender's ability to make the correct liquidation decision, unlike our paper, which emphasizes the informational role of the structure of the bank's claim for uninformed claimants.

\section{Conclusion}

In this paper we have examined a model of the optimal claim for a bank in a world where uninformed non-equity stakeholders--its long-time suppliers and customers--depend on the bank for truthful information about a borrowing firm's financial condition. In particular, stakeholders rely on the bank to reveal whether the borrowing firm is financially distressed and whether concessions are necessary. The bank's financial claim is designed to ensure that it cannot form a coalition with the firm's 
owners either to seek unnecessary concessions when the firm is actually healthy or to claim that the firm is healthy when it is actually in financial distress.

We show that the optimal claim has the following characteristics. To ensure that a healthy firm and the bank will not seek unnecessary concessions from stakeholders, the bank cannot hold an equity stake within some intermediate range; that is, the bank's equity share must either be very small or very large. Thus, there are stringent constraints on the bank's ability to take equity stakes in distressed firms. To ensure that the financially distressed firm and bank will not collude to claim falsely that the firm is healthy--a possibility that arises when managers' bargaining power is weak and bankruptcy costs are relatively small--a sufficiently large portion of the bank's financial claim on the healthy firm must be subordinated to stakeholders' claims. Since banks may have difficulties in credibly subordinating their debt claims, a bank equity share when the firm is healthy may be necessary. Thus, our analysis offers limited support for often-made claims that bank equity stakes in borrowing firms may enhance efficiency. 


\section{Appendix}

Proof of Lemma 1: Assume that $m_{h}<R_{b}$. Then the supplier's date 0 expected profits are no greater than

$$
\left[\mathrm{R}_{\mathrm{b}}-\mathrm{c}\right]
$$

and the supplier's participation constraint is violated since $R_{b}<c+v_{0}$, by assumption. We will show that $m_{d}<R_{b}$, so we must have $m_{h}>R_{b}$ or the supplier will not participate.

Assume that $m_{d}>R_{b}$. If this supply price leads to liquidation at date 1 , we have an ex post inefficient outcome given parametric restriction (1). In Propositions 1-3, we show that liquidation can be avoided, so liquidation is also ex ante inefficient. If the firm is not liquidated, the joint expected profits are:

$$
\theta\left[p_{h} R_{g}+\left(1-p_{h}\right)\left(R_{b}-B\right)\right]+(1-\theta)\left[p_{d} R_{g}+\left(1-p_{d}\right)\left(R_{b}-B\right)\right]-\left(X_{o}+X\right)-\left(c+v_{o}\right) .
$$

If, on the other hand, $\mathrm{m}_{\mathrm{d}}<\mathrm{R}_{\mathrm{b}}$, joint expected profits are:

$$
\theta\left[p_{h} R_{g}+\left(1-p_{h}\right)\left(R_{b}-B\right)\right]+(1-\theta)\left[p_{d} R_{g}+\left(1-p_{d}\right) R_{b}\right]-\left(X_{o}+X\right)-\left(c+v_{o}\right)
$$

which are clearly larger, because expected deadweight bankruptcy costs $(1-\theta)\left(1-\mathrm{p}_{\mathrm{d}}\right) \mathrm{B}$ are avoided.

Q.E.D.

\section{Proof of Proposition 2:}

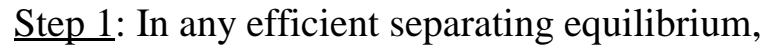

$$
\left\{a_{d}, D_{d}\right\} \neq\left\{a_{j}, D_{j}\right\}, j=h, d,
$$

Assume otherwise, and let $\{\mathrm{a}, \mathrm{D}\}$ be the bank's contractual claim in the stage 1 contractual agreement in both states and $m_{j}$ the offer made to the supplier in state $\mathrm{j}$. Thus, the bank's claim provides no information to the supplier. If the supplier were ever to accept $m_{d}<R_{b}$, the firm and bank would always collude to claim distress, and the supplier's participation constraint is violated. If the supplier always refuses to accept $\mathrm{m}_{\mathrm{d}}<\mathrm{R}_{\mathrm{b}}$, there is no restructuring, which is inefficient by Lemma 1 . 


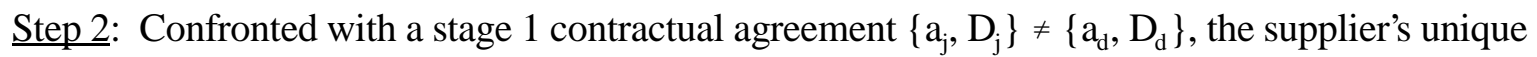
best response in stage 2 is to refuse any offer $m_{j}<m_{o}$.

Given (A.1) and the restriction to pure strategies, a supplier that sees stage 1 agreement $\left\{a_{j}, D_{j}\right\}$ $\neq\left\{a_{d}, D_{d}\right\}$ in equilibrium believes that the firm is healthy with probability 1 . If it refuses any offer below $\mathrm{m}_{\mathrm{o}}$, the original contract is in effect, and all agents will agree to continue under contractual outcome $\left\{\mathrm{a}_{\mathrm{o}}\right.$, $\left.\mathrm{D}_{\mathrm{o}}, \mathrm{m}_{\mathrm{o}}\right\}$. Clearly, the supplier's expected profits are higher when the price is higher (as long as the firm continues production).

Step 3: When the firm is healthy, the unique stage 1 equilibrium contractual agreement is $\left\{a_{0}\right.$, $\left.\mathrm{D}_{\mathrm{o}}\right\}$

If the supplier will reject any $\mathrm{m}_{\mathrm{j}}<\mathrm{m}_{\mathrm{o}}$, any revision of the initial contract reduces either the bank's or the healthy firm's profits. The bank would never propose a revision that reduces its own profits and the firm would always reject any revision that reduces its profits. Together, steps 2 and 3 establish that $\left\{a_{j}, D_{j}, m_{j}\right\}=\left\{a_{o}, D_{o}, m_{o}\right\}, j=h, s$.

Step 4: If the supplier accepts $m_{d}$ when the stage 1 agreement is $\left\{a_{d}, D_{d}\right\}$, there will exist states where the bank and a healthy firm will agree to $\left\{a_{d}, D_{d}\right\}$ and propose $m_{d}$ unless $a_{d}$ satisfies one of the following two conditions:

$$
\mathrm{a}_{\mathrm{d}} \leq \mathrm{a}_{\mathrm{d}}^{\mathrm{c}} \equiv\left[\frac{\pi^{\mathrm{b}}(\mathrm{h})-\pi^{\mathrm{b}}(\mathrm{d})}{\left(\mathrm{p}_{\mathrm{h}}-\mathrm{p}_{\mathrm{d}}\right)\left(\mathrm{R}_{\mathrm{g}}-\mathrm{R}_{\mathrm{b}}\right)}\right]
$$

or

$$
a_{d} \geq a_{d}^{f} \equiv a_{d}^{c}+\left[\frac{\pi^{\mathrm{s}}(h)-\left(m_{d}-c\right)}{\left(p_{h}-p_{d}\right)\left(R_{g}-R_{b}\right)}\right]>a_{d}^{c} .
$$

Conditions (A.2) and (A.3) are merely restatements of (4) and (5) in the text, where their 
derivations are explained.

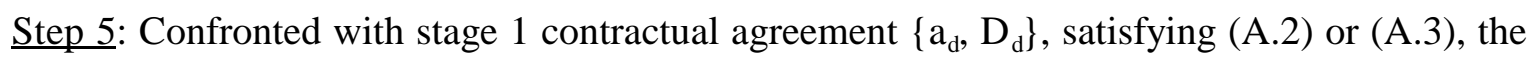
supplier's best response is to accept any offer $m_{d} \geq c+v$.

Since the supplier knows that the firm is in distress and that concessions are necessary when it observes $\left\{a_{d}, D_{d}\right\}$--given steps 3 and 4--the supplier does at least as well producing for the firm as when the firm is liquidated as long as $\mathrm{m}_{\mathrm{d}} \geq \mathrm{c}+\mathrm{v}$.

Step 6: In distress, the unique equilibrium stage 1 agreement satisfies $\pi^{\mathrm{f}}(\mathrm{d})=[\mathrm{w}, 0]^{+}$, and the unique stage 2 offer by the firm/bank coalition is $\mathrm{m}_{\mathrm{d}}=\mathrm{c}+\mathrm{v}$.

Assume that the stage 1 contractual agreement is $\left\{a_{d}, D_{d}\right\}$. Then, given Step 5, the firm/bank coalition's maximizing offer is the lowest price that would be accepted by the supplier. Then in stage 1, the bank's profits are maximized by making the firm just indifferent between continuation and liquidation. This establishes (7) and (8).

Step 7: This equilibrium can be sustained as long as the supplier adopts the strategy of rejecting $\mathrm{m}<\mathrm{m}_{\mathrm{o}}$ for any stage 1 agreement other than $\left\{\mathrm{a}_{\mathrm{d}}, \mathrm{D}_{\mathrm{d}}\right\}$, supported by supplier beliefs that the firm is healthy with probability one whenever the stage 1 agreement is not $\left\{a_{d}, D_{d}\right\}$.

\section{Q.E.D.}

Proof of Proposition 2: Assume that the bank's contractual claim on the distressed firm is a pure debt claim--which satisfies Proposition 1--so that the healthy firm and bank will not collude. Assume that the bank's initial claim is fully subordinated to the supplier's claim. The bank would never willingly claim that a distressed firm was healthy as long as,

$$
\pi^{\mathrm{b}}(\mathrm{d}) \geq \pi^{\mathrm{b}}(\mathrm{h} \mid \mathrm{d})=\pi^{\mathrm{b}}(\mathrm{h})-\left(\mathrm{p}_{\mathrm{h}}-\mathrm{p}_{\mathrm{d}}\right)\left(\varphi_{\mathrm{o}}-\left[\mathrm{R}_{\mathrm{b}}-\mathrm{B}-\mathrm{m}_{\mathrm{o}}, 0\right]^{+}\right.
$$

where

$$
\varphi_{\mathrm{o}} \equiv \mathrm{a}_{\mathrm{o}}\left[\mathrm{R}_{\mathrm{g}}-\mathrm{m}_{\mathrm{o}}-\mathrm{D}_{\mathrm{o}}\right]+\mathrm{D}_{\mathrm{o}}
$$


which is the value of the bank's initial financial claim when firm revenues are high. Since we have already shown that $\mathrm{m}_{\mathrm{o}}>\mathrm{R}_{\mathrm{b}}$, (A.4) can be rewritten,

$$
\left(\mathrm{p}_{\mathrm{h}}-\mathrm{p}_{\mathrm{d}}\right) \varphi_{\mathrm{o}} \geq \pi^{\mathrm{b}}(\mathrm{h})-\pi^{\mathrm{b}}(\mathrm{d})
$$

Since $\varphi_{\mathrm{o}}$ is determined by the bank's initial contractual claim, its structure may be an object of design but its expected value is fully determined by the bank's date 0 participation constraint. Furthermore, its structure does not affect whether (A.6) is satisfied. We conclude that the structure of the bank's initial claim is indeterminate; in particular, a pure debt claim will suffice.

Q.E.D.

Proof of Proposition 3: The distressed firm and the bank will not collude to claim falsely that the firm is actually healthy if either the firm's truth-telling condition holds-- $\pi^{\mathrm{f}}(\mathrm{d}) \geq \pi^{\mathrm{f}}(\mathrm{h} \mid \mathrm{d})$--or the bank's truth-telling condition holds-- $\pi^{\mathrm{b}}(\mathrm{d}) \geq \pi^{\mathrm{b}}(\mathrm{h} \mid \mathrm{d})$--or both hold. Equation (14) in the text shows that the distressed firm will be willing to collude for w sufficiently small, independent of the structure of the bank's claim or the relative priority of the bank's and stakeholder's fixed claims. Now assume that the bank's fixed claim has priority over the supplier's claim.

We can write:

$$
\pi^{\mathrm{b}}(\mathrm{h})=\mathrm{p}_{\mathrm{h}} \varphi_{\mathrm{o}}+\left(1-\mathrm{p}_{\mathrm{h}}\right) \mu_{\mathrm{o}}
$$

where $\varphi_{\mathrm{o}}$ was defined in the previous proof, and

$$
\mu_{\mathrm{o}} \equiv\left[\mathrm{R}_{\mathrm{b}}-\mathrm{B}, \mathrm{D}_{\mathrm{o}}\right]^{-}
$$

which is the value of the bank's initial contractual fixed claim when firm revenues are low and the bank has priority. Also,

$$
\pi^{\mathrm{b}}(\mathrm{h} \mid \mathrm{d})=\mathrm{p}_{\mathrm{d}} \varphi_{\mathrm{o}}+\left(1-\mathrm{p}_{\mathrm{d}}\right) \mu_{\mathrm{o}}
$$

so the bank's truth-telling condition when the firm is distressed can be written, 


$$
\varphi_{\mathrm{o}}-\mu_{\mathrm{o}} \geq \frac{\pi^{\mathrm{b}}(\mathrm{h})-\pi^{\mathrm{b}}(\mathrm{d})}{\mathrm{p}_{\mathrm{h}}-\mathrm{p}_{\mathrm{d}}}
$$

and since,

$$
\pi^{\mathrm{f}}(\mathrm{h} \mid \mathrm{d})=\mathrm{p}_{\mathrm{d}} \mathrm{R}_{\mathrm{g}}+\left(1-\mathrm{p}_{\mathrm{d}}\right)\left[\mathrm{R}_{\mathrm{b}}-\mathrm{B}\right]-\pi^{\mathrm{b}}(\mathrm{h} \mid \mathrm{d})-\pi^{\mathrm{f}}(\mathrm{h} \mid \mathrm{d}),
$$

the distressed firm's truth-telling condition can be written,

$$
\frac{\pi^{\mathrm{b}}(\mathrm{h})-\pi^{\mathrm{b}}(\mathrm{d})-\left(\mathrm{m}_{\mathrm{d}}-\mathrm{p}_{\mathrm{d}} \mathrm{m}_{\mathrm{o}}\right)+\left(1-\mathrm{p}_{\mathrm{d}}\right) \mathrm{B}}{\mathrm{p}_{\mathrm{h}}-\mathrm{p}_{\mathrm{d}}} \geq \varphi_{\mathrm{o}}-\mu_{\mathrm{o}}
$$

Reversing conditions (A.9) and (A.10) and combining, we see that a necessary condition for the bank and distressed firm to agree to collude to claim that the firm is actually healthy is that

$$
\left(m_{d}-p_{d} m_{o}\right)-\left(1-p_{d}\right) B>0,
$$

which is condition (13) in the text.

Assume that $\mathrm{w} \leq \mathrm{w}^{*}$ and that (A.11) holds so that the bank and the distressed firm might agree to collude, and assume that the bank holds no initial equity, i.e., $a_{o}=0$. Then (A.9) can be rewritten,

$$
\mathrm{D}_{\mathrm{o}}-\mu_{\mathrm{o}} \geq \frac{\pi^{\mathrm{b}}(\mathrm{h})-\pi^{\mathrm{b}}(\mathrm{d})}{\mathrm{p}_{\mathrm{h}}-\mathrm{p}_{\mathrm{d}}}
$$

If the bank holds no initial equity claim, the bank's date 0 participation requires that $D_{o}>R_{b}$, so with a little rearranging, (A.12) can be rewritten,

$$
-\left(\frac{\mathrm{p}_{\mathrm{d}}}{\mathrm{p}_{\mathrm{h}}-\mathrm{p}_{\mathrm{d}}}\right)\left(\mathrm{D}_{\mathrm{o}}-\left[\mathrm{R}_{\mathrm{b}}-\mathrm{B}\right]\right) \geq \frac{\left[\mathrm{R}_{\mathrm{b}}-\mathrm{B}\right]-\pi^{\mathrm{b}}(\mathrm{d})}{\mathrm{p}_{\mathrm{h}}-\mathrm{p}_{\mathrm{d}}} .
$$


To show that this cannot hold for B sufficiently small, take the limiting case as B approaches 0 , and (A.13) can be written,

$$
-\left(\frac{\mathrm{p}_{\mathrm{d}}}{\mathrm{p}_{\mathrm{h}}-\mathrm{p}_{\mathrm{d}}}\right)\left(\mathrm{D}_{\mathrm{o}}-\mathrm{R}_{\mathrm{b}}\right) \geq \frac{\mathrm{R}_{\mathrm{b}}-\pi^{\mathrm{b}}(\mathrm{d})}{\mathrm{p}_{\mathrm{d}}-\mathrm{p}_{\mathrm{h}}},
$$

a contradiction since $R_{b}>\pi^{b}(d)$. Thus, we must have $a_{o}>0$.

Using the definitions for $\varphi_{o}$ and $\mu_{\mathrm{o}}$, (A.9) can be rearranged to solve for the minimum initial equity share that will ensure that the bank will be truthful:

$$
a_{o} \geq \frac{\pi^{b}(h)-\pi^{b}(d)}{\left(p_{h}-p_{d}\right)\left(R_{g}-m_{o}-D_{o}\right)}+\frac{\left[R_{b}-B, D_{o}\right]^{-}-D_{o}}{R_{g}-m_{o}-D_{o}}
$$

Q.E.D. 


\section{Footnotes}

1. Researchers have documented that the costs of financial distress are lower for those firms that maintain close bank ties (Hodder (1986), Hoshi, Kashyap, and Scharfstein (1990), and Kester (1991)) and that firms with close bank ties are less likely to curtail investments when internal funds are low (Hoshi, Kashyap and Scharfstein (1991)).

2. Edwards and Fischer (1994) argue quite strenuously against the view that German banks play a special role in reducing the costs of financial distress. On the other side, Harm (1994) finds evidence that close bank ties reduce liquidity constraints for small firms.

3. It is straightforward that a bank equity share might help resolve conflicts of interest between the firm's shareholders and the bank about project risk or maturity. However, we do not subscribe to the common belief that there are any simple relationships between a bank's equity stake and: (i) its information about the firm, or (ii) its power to influence firm affairs. Information and power should flow to large investors whether or not their claim includes an equity component. This is especially true in distress, when creditors' influence is greatest. We do believe that the precise relationship between the debt-equity structure of the bank's claim and its power to influence firm behavior is an important topic for research.

4. In James's (1993) sample, banks do take equity in 30\% of the distressed restructurings, not an inconsequential number. At the same time, banks do not take equity in the vast majority of the cases, and the presence and weight of other creditors seem to be the most important constraint. Notably, for those cases in which banks do take equity as part of the distressed restructuring, the median share of public debt in the firm's total debt is zero. James' results are echoed in a number of other recent studies. For example, Gilson (1993) finds that firms exit from a distressed restructuring with surprisingly high debt-equity ratios and that a firm's debt-equity ratio coming out of a 
restructuring is positively related to the amount of the firm's bank debt entering distress. Gilson, John, and Lang (1990) find that bank and insurance company debt is converted into common stock less often than other creditors' debt.

5. For Japan, see Flath (1993) and Prowse (1992). For Germany, see Harm (1993). Also see Gorton and Shmid (1994) and Cable (1985) for conflicting evidence that German banks' equity positions affect firm performance more generally.

6. See James (1993) for a thorough description of current regulations in the U.S.

7. Hodder (1986) and Kester (1991) emphasize the role of Japanese banks in resolving conflicts between firm owners and non-equity stakeholders when firms enter into financial distress. Fama (1990) emphasizes that bankers play a key role in communicating relevant information to stakeholders in their lending decisions.

8. Our emphasis on the bank's role in financial distress and on potential conflicts among claimants is broadly consistent with our reading of the empirical evidence as described above. It should be noted that while empirical work on financial distress has emphasized potential conflicts among financial claimants, it has not focused on stakeholders. As we proceed, we will indicate how stakeholders in general might differ from public bondholders.

9. See White (1981) for a discussion of the reasons why banks can effectively increase the priority of their claims in financial distress. Also see Slovin, Shuska, and Waller (1993).

10. Thus, our model provides a rationale for self-imposed constraints on substantial bank equity shares in financially distressed firms, rooted in conflicts of interest among fixed claimants and the bank's pivotal role in distressed restructurings. It also provides some support for arguments that bank equity holdings in healthy firms may enhance efficiency.

11. Two recent papers, Kim (1992) and Pozdena (1991) have models that show it is optimal for 
banks to hold equity in borrowing firms. In both cases, the bank--which is assumed to be the sole source of funds--is essentially a passive substitute for the firm's capital structure, rather than an independent actor whose behavior is affected by the structure of its claim. Thus, both models are essentially models of capital structure, rather than models of the optimal claim for an informed investor.

12. The assumption of a zero initial investment by the firm's owners is merely a scaling convention that could easily be relaxed at the cost of adding a period 0 participation constraint for the firm's owners.

13. In our paper, the availability of a less informed alternative funding source would affect none of our results in a material way. The bank's bargaining power derives from its superior information about the firm's financial health, not from its position as the firm's sole financier.

14. In our model, the only role of bankruptcy costs is to ensure the inefficiency of an equilibrium where claims are not restructured in financial distress, that is, where there is no real need for an informed lender to facilitate restructurings.

15. Although the bank's informational monopoly gives the bank substantial market power, our model does not incorporate the types of distortions that can arise due to ex post market power as in Sharpe (1990) or Rajan (1992).

16. With minor modeling changes, the stakeholder could also be a buyer of the firm's products. In this interpretation, the buyer must make a binding decision at date 1 whether to purchase the firm's product in preference to some standardized alternative, and delivery cannot occur until date 2 . 17. In principle, we could imagine our uninformed stakeholders collateralizing their own claims or placing "no subordination" covenants in their supply contracts. Taking collateral--which requires continued monitoring to ensure the value and maintenance of the value of the assets--is foreclosed by 
precisely the same information costs that lead the stakeholders to defer information collection about the firm's financial condition to the bank. In the context of contracts to supply or purchase goods or services, the transactions costs and the operating inflexibility that would afflict any attempt to specify contractually those subsequent claims--real and financial--that can or cannot be given priority would be considerable.

18. Our qualitative results would hold for many other bargaining games (which would lead to less extreme distributions of the bargaining surplus). Only two features of our bargaining setup are essential: (i) The firm and the bank must be able to negotiate in private before an offer is made to the supplier--this introduces the possibility that the firm and the bank might form a coalition to expropriate the supplier. (ii) The supplier and the firm must have some power to enforce the terms of the initial contract when the initial contract is feasible. If this were not the case, suppliers would never enter into initial supply relationships and firms would never contract with banks. We give the supplier and the firm bargaining power by assuming that they can always reject an offer in favor of the initial contract.

19. Hopefully without confusion, we use the same notation for the agents' payoff functions under both assumptions about relative priority. In subsequent sections we will be clear about which assumption and which payoff functions are being used.

20. There also exist inefficient pooling equilibria, in which the supplier always refuses to make concessions.

21. The reader should note that $a_{d}^{f}>a_{d}^{c}$ follows directly from the supplier's date 0 participation constraint.

22. The inequality in (11) is derived by noting that $\pi^{\mathrm{f}}(i \mid j)=\mathrm{p}_{\mathrm{j}} R_{\mathrm{g}}+\left(1-\mathrm{p}_{\mathrm{j}}\right) \mathrm{R}_{\mathrm{b}}-\pi^{\mathrm{s}}(\mathrm{i} \mid \mathrm{j})-\pi^{\mathrm{b}}(\mathrm{i} \mid \mathrm{j})$, and substituting the equality in (9) and the value of $\mathrm{a}_{\mathrm{d}}^{\mathrm{c}}$ from (4). 
23. Although our model permits the bank to take large equity shares in distress, we prefer to focus on the ceiling $\left(\mathrm{a}_{\mathrm{d}}^{\mathrm{c}}\right)$ on the bank's possible equity share. While a pure debt claim in distress is always feasible, there is no assurance that $\mathrm{a}_{\mathrm{d}}^{\mathrm{f}}<1$, that is, an equity share large enough to prevent collusion may be infeasible. Further, if managerial effort (which we have not modeled) is important, a very large bank equity share may be infeasible for incentive reasons.

24. See fn.3 and fn.5 for the relevant references. The existing empirical literature emphasizes the role of conflicts among financial claimants. A direct test of the empirical importance of the factors driving our model would examine how the outcomes of distressed restructurings are affected by the relative importance of dedicated supply relationships in firms' input and output markets.

25. When the bank holds no equity, the inequality $D_{o}>R_{b}$ follows directly from the bank's date 0 participation constraint.

26. The reader should note that the only role of deadweight bankruptcy costs in our model is to ensure that a pooling outcome without the restructuring of claims is inefficient. Without deadweight bankruptcy costs, there is an efficient pooling equilibrium where the supplier always refuses to renegotiate and the firm avoids liquidation whether it is healthy or distressed (if $\mathrm{w}$ is low enough). Note that our results hold even if bankruptcy costs are quite small. In fact, if bankruptcy costs are too large, the bank would always prefer to reveal truthfully that the firm is distressed--as inequality (13) states--and the priority of the bank's claim is irrelevant.

27. Of course, there are other reasons outside our model why a bank's normal claim will include debt, even when the bank is well informed. Recent models of optimal capital structure as a means of assigning control rights in the presence of non-transferable sources of utility for managers (e.g., Aghion and Bolton (1992) and Hart and Moore (1989)) or prior uncertainty about managerial abilities (e.g., Kalay and Zender (1992)) would predict that even an informed investor will hold at 
least a partial debt claim. An attempt to integrate our emphasis on conflicts among claimants and the control rights literature would be an interesting (and difficult) avenue for future research.

28. For example, Baums (1994) cites a study which examines the reasons for German banks taking equity stakes of $25 \%$ or more in the period 1976-1989. Of 21 cases, one-half involve a desire by dominant shareholders (or their family members) to reduce their equity positions. Interesting, only a small number (3) were banks taking equity stakes in distressed firms. 